\title{
The Scottish Legendary
}

Towards a poetics of hagiographic narration

EVA VON CONTZEN

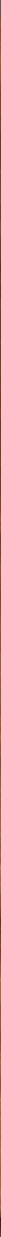




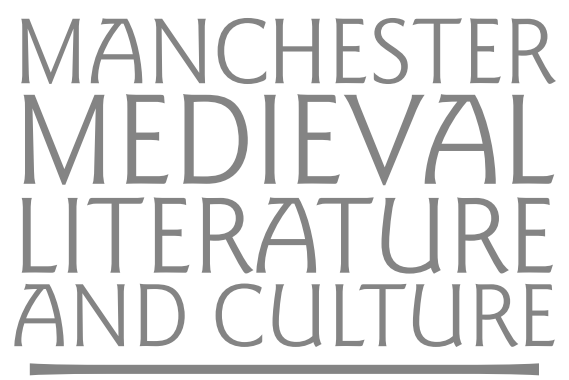

THE SCOTTISH LEGENDARY

\section{MANCHESTER 1824}

Manchester University Press 
Series editors: Anke Bernau and David Matthews

Series founded by: J. J. Anderson and Gail Ashton

Advisory board: Ruth Evans, Nicola McDonald, Andrew James Johnston, Sarah Salih, Larry Scanlon and Stephanie Trigg

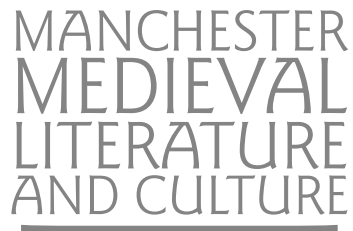

The Manchester Medieval Literature and Culture series publishes new research, informed by current critical methodologies, on the literary cultures of medieval Britain (including Anglo-Norman, Anglo-Latin and Celtic writings), including post-medieval engagements with and representations of the Middle Ages (medievalism). 'Literature' is viewed in a broad and inclusive sense, embracing imaginative, historical, political, scientific, dramatic and religious writings. The series offers monographs and essay collections, as well as editions and translations of texts.

\section{Titles Available in the Series}

The Parkment of Foulys (by Geoffrey Chaucer)

D. S. Brewer (ed.)

Language and imagination in the Gawain-poems

J. J. Anderson

Water and fire: The myth of the Flood in Anglo-Saxon England

Daniel Anlezark

Greenery: Ecocritical readings of late medieval English literature

Gillian Rudd

Sanctity and pornography in medieval culture: On the verge

Bill Burgwinkle and Cary Howie

In strange countries: Middle English literature and its afterlife:

Essays in Memory of J.J. Anderson

David Matthews (ed.)

A Knight's Legacy: Mandeville and Mandevillian Lore in early modern England Ladan Niayesh (ed.)

Rethinking the South English legendaries

Heather Blurton and Jocelyn Wogan-Browne (eds)

Between earth and heaven: Liminality and the Ascension of Christ

in Anglo-Saxon literature

Johanna Kramer

Transporting Chaucer

Helen Barr

Sanctity as literature in late medieval Britain

Eva von Contzen and Anke Bernau (eds)

Reading Robin Hood: Content, form and reception in the outlaw myth

Stephen Knight

Annotated Chaucer bibliography: 1997-2010

Mark Allen and Stephanie Amsel

Roadworks: Medieval Britain, medieval roads

Valerie Allen and Ruth Evans (eds)

Love, history and emotion in Chaucer and Shakespeare:

Troilus and Criseyde and Troilus and Cressida

Andrew James Johnston, Russell West-Pavlov and Elisabeth Kempf (eds)

Gesta Romanorum: A new translation

Christopher Stace 


\section{The Scottish Legendary}

Towards a poetics of hagiographic narration

EVA VON CONTZEN

Manchester University Press 
Copyright (C) Eva von Contzen 2016

The right of Eva von Contzen to be identified as the author of this work has been asserted by her in accordance with the Copyright, Designs and Patents Act 1988.

Published by Manchester University Press

Altrincham Street, Manchester M1 7JA

www.manchesteruniversitypress.co.uk

British Library Cataloguing-in-Publication Data

A catalogue record for this book is available from the British Library

Library of Congress Cataloging-in-Publication Data applied for

ISBN 9780719095962 hardback

First published 2016

The publisher has no responsibility for the persistence or accuracy of URLs for any external or third-party internet websites referred to in this book, and does not guarantee that any content on such websites is, or will remain, accurate or appropriate.

Typeset by Out of House Publishing 